brazilianpoliticalsciencereview

BOOK REVIEW

\title{
Academic Accomplishments within the Free Trade
}

\section{Debate*}

\author{
by Michelle Ratton Sanchez Badin \\ Fundação Getúlio Vargas, Brazil
}

(von BÜLOW, Marisa. A batalha do livre comércio: a construção de redes transnacionais da sociedade civil nas Américas. São Paulo: Editora UNESP, 2014)

or the contemporary reader, especially a young Brazilian academic, it
may not be clear that the debate on free trade has assumed different nuances since 1990. If at that time the issue was strictly related with a neoliberal agenda and, therefore, focused solely on market efficiency while being restricted to a few group of economists and market players, the current debate expands well beyond this sphere. Many other agents have joined this debate and by questioning the neoliberal economic principles they have complexified and relativized the theme of economic efficiency. The reading of Marisa von Bülow's book helps to trace these changes with great clarity and methodological precision in regards to the involvement of social movements in this agenda within the Americas.

In her book the author analyzes the creation of transnational networks among civil society agents so as to coordinate activities on topics pertaining to international trade. The title "the battle" is represented within the analysis, on the one hand, by the formation of the contestation discourse (Part II - "the politicization of trade"), and secondly, by the forms by which social movements have been organized (Part III - "the dynamics of networks" - and Part IV - "organizational pathways to trans-nationality"). Contestation is therefore under the spotlight in this book.

(*) http://dx.doi.org/10.1590/1981-38212014000100023 
When describing the "battle", Marisa von Bülow's research brings conceptual and analytical "accomplishments" to the academic debate on international trade, and its social and civic dimension. The number of skeptics still to this date on the role of social movements in this field is not trivial. There is distrust regarding the ability to understand the technical dimension of the international trade regulation, as well as the ability of these agents to interfere at different levels of decision-making. The book elucidates the formation of transnational social movement networks and its discourse, identifying the actors (name, location and agenda) as well as the bases and the formation of an articulated contestation discourse (themes and proposals).

Networks have been a central issue in social sciences in recent decades: how they are formed, how do they operate, financing forms, and the results from this coordination. The book corresponds to von Bülow's doctoral thesis at Johns Hopkins University, in the United States, being advised by Margareth Keck. Keck and Kathryn Sikkink co-authored one of the most influential articles under the theme of social movements and their transnational activities (Keck and Sikkink, 1998). Von Bülow's text is an application and specification of this larger project from Keck, in the tropics. The author analyzes the formation of transnational networks in the Americas and focuses on civil society organizations and movements based in Brazil, Chile, United States, and Mexico.

The focus in the Americas contributes to the mapping of a process - the participation from civil society -, which still looms in institutional terms, especially in South America. In order to understand the key actors and their coordination, it helps to outline the potentials and limits of social participation within this particular context of the Americas, the sub-region of South America and also, more specifically, of Brazil and its foreign policy.

Below I point out some key contributions that I identified in Marisa's work for the debates concerning international trade, social participation, and institutionalization of participatory mechanisms.

Trade without exclusion. The author justifies her thematic selection based on the controversy and articulation it has acquired since the 1990s (page 25). A first step debunked in the book, however, is that such movements are not opposed to capitalism or against trade per se, but against the (neoliberal) trade discourse that 
has prevailed since 1990s (page 70). Within this context an analysis of asymmetries and the North-South contraposition are performed in the book in several passages, with notes on the asymmetries of participants at different levels (e.g. at pages 51, 159, 207-9; and pages 253 and onwards). The "battle of free trade", in this case, acquires its driving force by problematizing exclusion.

The domestic context is part of the essence. As early as in the book's introduction, Marisa von Bülow discards the comprehension of social movements as being global agents (page 17), and clarifies over the course of her analysis how important the domestic context stands for transnational action (e.g. at page. 91). The domestic context is important both for problematizing issues as well as for the formation of discourse as a space of action. This observation is what supports the typology presented by the author about the degree of internationalization and of durability of those movements. These types refer to the degree of internalization of action (at a domestic political level) alongside the degree of the transnationalization process (pages 43, 46 and 52). The analysis made by the author in this theoretical section of the book is the book's main contribution as far as it is confirmed by the empirical results in the next sections.

Old values, new dynamics. Trust, according to the author, is a decisive relational element for internationalization. It empowers alliances, and the dissemination of ideas. The empirical analysis evidences that trust is based on preexisting ties or otherwise (page 91), and may have functional or thematic tints or otherwise (page 108).

What are the main transnational movements in the region? How do they articulate themselves? In part III of the book, the author systematizes her empirical data - the heart of the work -, and allows us to identify the networks and their allies. Chapters 5 and 6 describe the results of the empirical research as to how organization networks and movements critical of international trade agreements in the Americas were formed. In these chapters, Marisa von Bülow presents schemes derived from her interviews in order to identify how networks were structured in selected countries - Brazil, Chile, USA, and Mexico - always with the intent of identifying the chief central actors in this process.

The mapping registers the leading role of trade union, religious, and rural movements throughout the Americas. In the case of Brazil, the Landless Movement 
(MST), the Central Workers Union (CUT), and the Brazilian Institute of Social and Economic Analyses (Ibase) were the most often cited by organizations from other countries in shaping their transnational alliances. This is a major contribution brought forth by this book, allowing us to identify the agents present in transnational networks and to understand in detail the political process within networks. I bet that few are experts in international trade in Brazil - from academics to policymakers - who have the clarity of this data.

Organizational longevity as the main challenge. In chapters 07 and 08, Marisa von Bülow works on the challenges for transnational networks in building consensus, and on organizational longevity of campaigns and networks. Thus, the author concludes that "(The) challenge is to focus on the dynamic interactions and influences that intersect the domestic and international scales since, for the most part, transnational collective action entails an ambiguous combination of targets, networks, discourses and goals that are both domestic and international" (page 251) (free translation into English).

In short, the book brings important contributions both to the fieldwork data dealing with transnational networks in the Americas, and to the analytical model for this type of articulation.

Regarding the mapping of networks on trade agreements the book presents a relevant record for academics and policymakers who today pore over the institutionalization of direct participation channels in the formulation of Brazilian foreign policy and within certain international organizations.

As for Marisa von Bülow's analytical model, it may be further explored both in relation to other networks in the field of international trade itself and to transnational networks within other themes. For example, it could be placed under questioning whether in countries with a less liberal trade agenda - such as Bolivia and Venezuela - the conclusions would be similar to those reached in von Bülow's book. Moreover, what could be the impact of alignments between government and civil society movements within this contestation agenda? Marisa suggests some points in the final section of her book (pages 250 and ff.), but it is certain that this story is still being written in the Americas, and with many uncertainties still pervading contemporary times. Therefore, hereby is a suggestion for works that has yet to be written... 
bpsr Michelle Ratton Sanchez Badin

Translated by Paulo Scarpa

Reference

KECK, Margareth and SIKKINK, Kathryn (1998), Activists beyond Borders: Advocacy Networks in International Politics. New York: Cornell University Press. 